\title{
Bearing Capacity of Composite Joints of U-shaped Steel Composite Beams and Concrete- filled Square Steel Tubular Columns Based on Channel Steel Connection
}

\author{
Zaihua Zhang ${ }^{1, *}$, Guangxiang Mao ${ }^{1}$, Ran He${ }^{1}$, Alin Xiao' and Zelong Liu ${ }^{3}$ \\ ${ }^{1}$ College of Civil Engineering, Hunan City University, Yiyang, Hunan, 410003, China \\ ${ }^{2}$ Zhongmin Zhuyou Technology Co., Ltd,Changsha, 410000, China \\ ${ }^{3}$ Department of Civil Engineering, University of Auckland, Auckland 1010, New Zealand
}

Received 8 June 2021; Accepted 14 August 2021

\begin{abstract}
Traditional beam-column connection structures fail to meet design requirements of hidden beams and columns in the application of composite frames formed by U-shaped steel composite beams (USCBs) and concrete-filled square steel tubular columns (CFSTBCs) to residential buildings. Therefore, a novel beam-column connection structure of U-shaped steel composite beams and concrete-filled steel tubular columns based on channel steel connections was proposed in this study. An experimental study and finite element simulation analysis of the joint performance of the novel composite frame side joint specimen under monotonic load were carried out. Failure mode and bearing capacity of joints under negative bending moment were discussed based on the experimental investigation of two full-scale joints. The influence of beam section height, width-thickness ratio of column, and axial compression ratio on the bearing capacity of joints was explored by analyzing parameters of the finite element model. Results demonstrate that failure form of the joint is tensile crack of concrete floor at flange of core area of the joint under the action of negative bending moment, ductility coefficient of the joint is greater than 2.0, and bearing and ductility performance is excellent. Beam section height significantly influences the bearing capacity of joints, while the width-thickness ratio of the steel tube column slightly influences the bearing capacity of joints when the requirement of "strong columns and weak beams" is met. The bearing capacity of the joint is minimally affected by the change of axial compression ratio when the axial compression ratio of the column is less than or equal to 0.6. However, the bearing capacity is significantly reduced with the increase of the axial compression ratio when the axial compression ratio is greater than 0.6 . This study can provide a theoretical basis for the engineering application and popularization of the novel composite frame beam-column connection structure.
\end{abstract}

Keywords: Channel steel penetration connection, U-shaped steel composite beam (USCB), concrete-filled square steel tubular column (CFSTBC), bearing capacity

\section{Introduction}

U-shaped steel composite beams join cold-formed or welded U-shaped steel beams and concrete slabs by setting appropriate shear connectors [1-4]. The novel composite beam presents better stability and fire resistance compared with the traditional $\mathrm{H}$-shaped steel beam due to the concrete in the U-shaped steel beam. Composite beams are increasingly applied to structural systems given the excellent performance of the new section. The composite frame structure formed by the U-shaped steel composite beam and concrete-filled steel tube column is a typical application. Similar to the U-shaped steel composite beam, the concretefilled steel tubular column is also a composite section with high strength and satisfactory stiffness, fire resistance, and earthquake resistance [5]. The new composite frame structure demonstrates high application potential. However, the application of U-shaped steel-concrete composite beamconcrete-filled steel tubular column composite frame in practical engineering is still limited given that studies on the beam-column connection of the novel composite frame structure are lacking.

*E-mail address: zaihua_zhang@163.com ISSN: 1791-2377 @ 2021 School of Science, IHU. All rights reserved. doi:10.25103/jestr.144.06
Existing typical beam-column connection structures of the U-shaped steel composite beam-concrete-filled steel tubular column composite frame include inner diaphragm, penetrated diaphragm, and outer ring plate. Although Chinese scholars have carried out in-depth studies on the joint performance of typical beam-column connection structures [6-10], these connection structures are suitable for public buildings with large column sections instead of composite frames used in residential buildings. The connection of inner diaphragm increases the difficulty in welding because of the small cross section of frame columns in residential buildings. Diaphragm penetration and outer ring plate influence the use of residential buildings and increase the difficulty in meeting design requirements of hidden beams and columns. Moreover, steel consumption is large. Theref ore, addressing the beam-column connection structure of the small-section concrete-filled steel tubular column-U-shaped steel concrete composite frame structure in residential buildings is urgently necessary.

A beam-column connection structure of U-shaped steel composite beams and concrete-filled steel tubular columns based on channel steel penetration is proposed in this study. Moreover, the bearing capacity of this novel connection structure are experimentally investigated and analyzed. 


\section{State of the art}

U-shaped steel-concrete composite beam is a novel composite member with excellent cross-sectional performance. Mechanical properties and engineering application of U-shaped steel-concrete composite beams have been intensively investigated in recent years. Oehlers [11] and Hossain [12] carried out a series of experimental investigations on flexural behavior of U-shaped steelencased concrete composite beams. The results demonstrated that bond strength between the encased steel and the concrete is low and reasonable shear connectors can ensure the operation of encased steel and concrete. Evident restraint effects of wrapped steel on the core concrete improve the performance of the core concrete. Meanwhile, the concrete can effectively improve the buckling bearing capacity of steel plates. However, these studies only considered concrete pouring inside the U-shaped steel and neglected the setting of concrete flange plate on the upper part of the U-shaped steel section. Kim S M [13], Kim S S [14], and Kim S.B. et al. [15] revealed performance advantages of U-shaped steel-concrete composite beams by performing a comparative experiment with traditional $\mathrm{H}$ shaped steel composite beams. The formula for flexural capacity of U-shaped steel-concrete composite beams was presented through experimental and theoretical analyses, but the mechanical performance of beams under negative bending moment was ignored. Kim J H [16] thoroughly analyzed the design method of U-shaped steel-concrete composite beams on the basis of European codes and discussed welded section of thin-walled steel plates. Zhou Xuhong [17] and Liu Jiepeng [18] put forward a U-shaped steel-concrete composite beam (RCUCB) with trussreinforced U-shaped steel section and reversed U-shaped steel bar as the shear connector and developed the calculation method for section bending design on the basis of European (EC4) and Chinese (JGJ 138) codes. Zhao Yi et al. [19-21] carried out a detailed exploration of negative moment bearing capacity, shear performance of inclined section, and bending stiffness of composite beam section and put forward the design checking formula of the RCUCB section engineering design. Turetta et al. [22,23] proposed a U-shaped steel section welded by a hot-rolled steel plate (bottom plate) and two Z-shaped cold-formed steel plates (side plates) and examined the bearing capacity of the Ushaped steel composite section beam. South Korea scholar Lee M H $[24,25]$ put forward a U-shaped steel composite section with hat-shaped perforated steel plate as the connector to enhance the height of floor structure and section performance. Liuyong et al. [26-28] developed a Ushaped steel-concrete composite beam section with welded angle steel as the shear connector, revealed force transmission mechanism of the shear connector, and introduced the analysis and design method of the composite beam. Keo P [29] pointed out that angle steel connectors effectively transfer not only shear force but also strengthen the U-shaped steel section by carrying out an experimental investigation on U-shaped steel composite beams with welded angle steel connectors.

The beam-column connection performance of various composite frames formed on the basis of U-shaped steel composite beams has gradually attracted considerable research attention because the cross-section performance of U-shaped steel composite beams has been thoroughly investigated. Park H G et al. [30,31] established a connection structure in which U-shaped steel beams directly penetrate through beam-column joint domain. The experimental study on the full-scale beam-column model verified that the connection structure presents acceptable seismic performance. However, this connection structure is seldom used in practical engineering because of its complexity. Lee $\mathrm{C} \mathrm{H}$ et al. [32-34] proposed a connection structure with beam end stiffeners for the beam-column connection of the composite frame formed by U-shaped steel composite beams and $\mathrm{H}$-shaped steel columns on the basis of the beam-column connection of the traditional composite frame of $\mathrm{H}$-shaped steel composite beams and H-shaped steel columns. Reliability of the connection structure was verified via the experimental investigation of the seismic performance of edge and intermediate nodes of the composite frame. Requirements for the construction quality of beam end weld are high due to the small thickness of the steel plate with U-shaped steel section. Hwang H J et al. [35, 36] assessed the seismic behavior of composite joints formed by U-shaped steel composite beams and angle steelreinforced concrete columns and put forward a calculation method for joint bearing capacity based on plastic stress distribution method. Kim S.B. [37] revealed the failure mode and bearing capacity by exploring the mechanical behavior of the joint of U-shaped steel composite beams and rigid reinforced concrete columns under positive and negative bending moments. Chinese scholars have also carried out numerous studies on the beam-column connection of composite frame formed by U-shaped steel composite beams and concrete-filled steel tubular columns. Lu Ming [38] examined the seismic performance of composite joints of $U-$ shaped steel composite beams and circular concrete-filled steel tubular columns on the basis of the beam-column outer ring plate connection structure and revealed that the outer ring plate connection structure is convenient for construction and demonstrates acceptable ductility. Lin Yan [7] and Zhou Xuejun et al. [8] designed and developed two types of Ushaped steel composite beam-concrete-filled square steel tubular column composite joints partitioned through reinforced penetration and truncation. According to the seismic performance test, the joint demonstrates satisfactory ductility and its performance is highly affected by the quality of welding between the partition and steel column. Liu Yong et al. [6] carried out low-cycle tests on joints of U-shaped steel composite beams and concrete-filled square steel tubular columns with inner partition and outer ring plates and revealed that joints of beam-column connections demonstrate acceptable seismic resistance. Wu Zishan [39] proposed a kind of CFST column-U-shaped steel-concrete composite beam partition through reinforced sleeve joint. The experimental study verified the reliability of the connection structure and helped develop the calculation method of shear capacity of the new joint. The French scholar Lepourry $[40,41]$ proposed the welded connection structure with angle steel stiffening using the beam-column connection of single-story portal steel frame structure formed by concrete-filled steel tubular columns and Ushaped steel composite beams. The results of the joint performance test showed the satisfactory ductility and bearing capacity of the portal steel frame joint.

Existing studies have shown that clear differences exist in the force transfer mechanism and bearing capacity of joints between U-shaped steel composite beams and frame columns with different connection structures. Composite joints of U-shaped steel composite beams and concrete-filled square steel tubular columns have progressed considerably. However, the cross section of steel tubular columns is small 
and hidden beams and columns are designed for concretefilled steel tubular composite frames in residential construction projects. The existing beam-column connection structure fails to meet the above requirements. A beamcolumn connection structure with through-channel steel connectors based on the above design requirements was proposed in this study. Two full-size joints were designed and prepared for edge joints of the new composite frame, and the bearing performance test and finite element analysis of joints under monotonic load were carried out. An experimental investigation was performed to examine failure modes and bearing performance of joints under negative bending moment. Meanwhile, parameter analysis of influencing factors of the joint performance was conducted based on the finite element simulation analysis. The results provided a basis for further theoretical analysis of the design and calculation of through-channel steel beam-column composite joints.

The remainder of this study is structured as follows. The general situation of the experiment is described in Section 3. The test results of the joint failure mode and loaddisplacement and moment-rotation relationships are compared and analyzed and parameter analysis of influencing factors of the performance of the novel composite joint is carried out on the basis of the finite element simulation analysis in Section 4. Finally, this study is summarized and relevant conclusions are drawn in Section 5 .

\section{Methodology}

\subsection{Construction of novel edge joint}

The beam-column edge joint of the U-shaped steel composite beam-concrete-filled square steel tubular column composite frame is constructed as follows. Two connecting channel steels penetrating the cross section of the concretefilled steel tubular column are arranged in the direction of primary and secondary beams at the joint. The connection channel steel is welded with the column. Connecting channel steels of secondary beams penetrate the concrete-filled steel tubular column and main beam channel steels, while Ushaped main and secondary beams penetrate the joint domain by welding with connecting channel steels. Negative reinforcement is arranged in the upper part of the concrete floor and the end of the reinforcement is welded on the wall of the steel pipe column in the direction of the main beam. The reinforced truss floor slab is used for the concrete floor. The steel truss floor slab is lowered by $15 \mathrm{~mm}$ and the lower edge of truss floor slab is welded to the upper flange of the U-shaped beam to improve the composite effect. Fig. 1 shows the three-dimensional structure of the edge joint in detail. Fig. 2 presents the diagram of cross-sectional geometric parameters of composite beams with U-shaped steel girder.
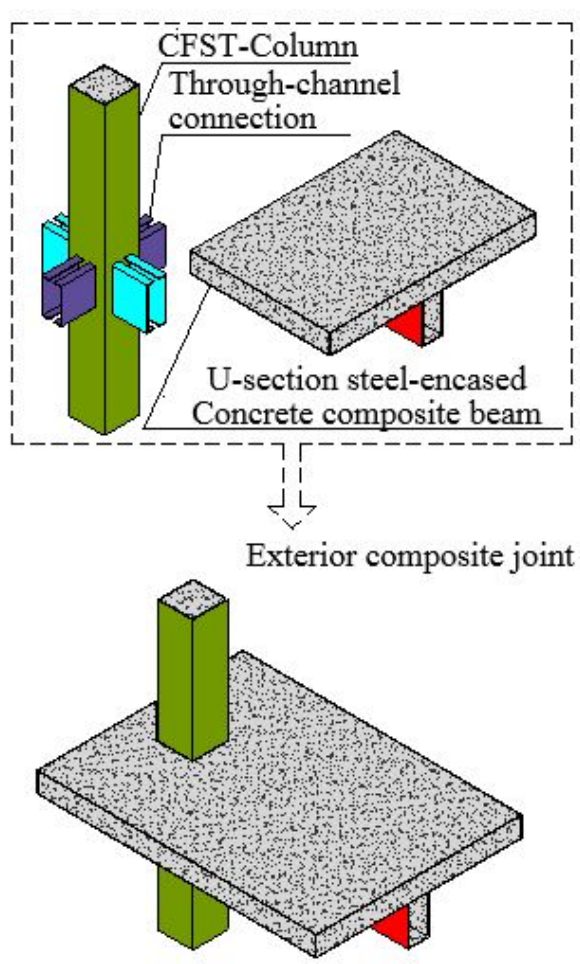

(a) Composite of the joint

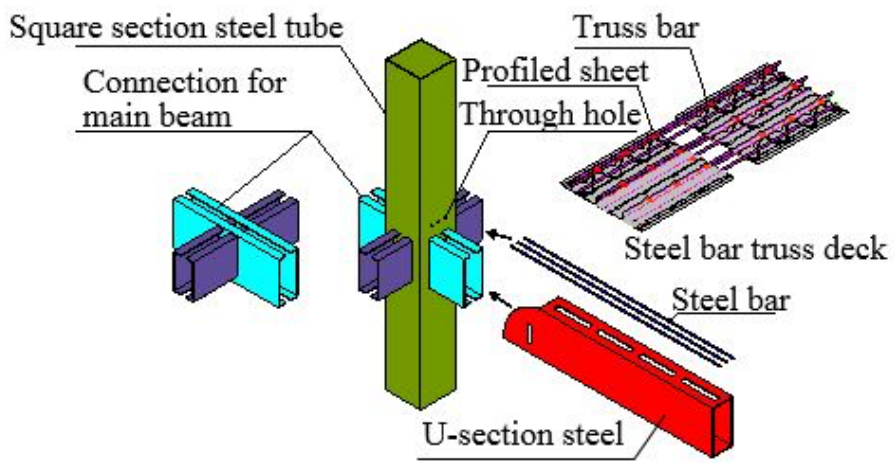

(b) Steel composite of the joint

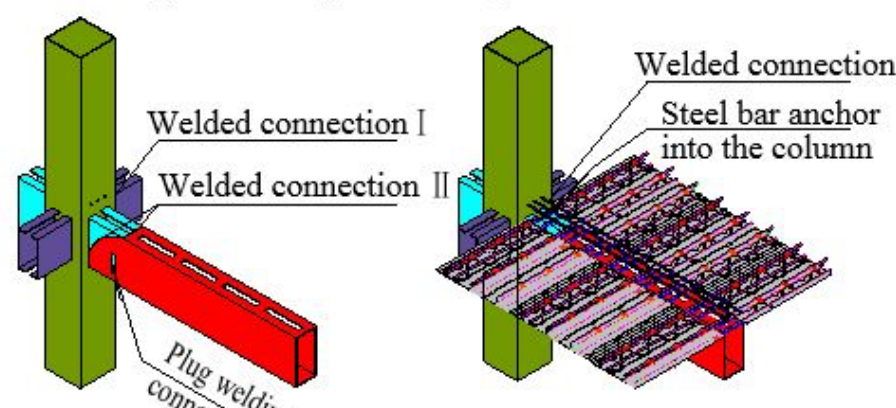

(d) Assembly method for floor deck to U-type beam

Fig. 1. Composition and configuration of channel-through type composite joint. (a) Composition of the joint. (b) Steel component of the joint. (c) Assembly method for U-type beam to column. (d) Assembly method for floor to U-type beam. 
Zaihua Zhang, Guangxiang Mao, Ran He, Alin Xiao and Zelong Liu/

Journal of Engineering Science and Technology Review 14 (4) (2021) 40 - 52
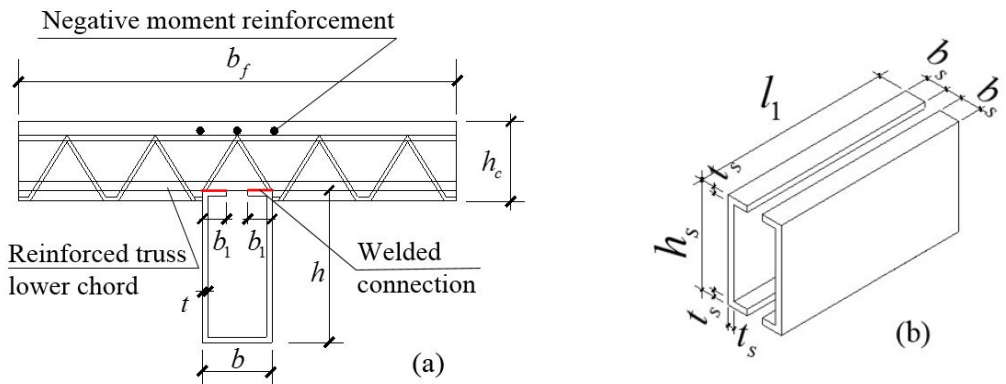

Fig. 2. Section of the U-shaped composite beam and the connected channel steel. (a) U-shaped composite beam. (b) Connected channel steel.

\subsection{Specimen design and manufacturing}

Two specimens (SJ-1 and SJ-2) were designed and manufactured, with the height of the main beam as the artificial control factor. Table 1 shows the specific dimensions of each specimen. $b_{c}$ is the side length of the steel tube column. $t$ is the wall thickness of the steel pipe column, $l$ is the length of the U-shaped composite beam. $h$ is the height of the U-shaped steel beam, $b$ is the width of the U-shaped steel beam, $b_{1}$ is the flange width of the Ushaped encased steel beam, and $t_{1}$ is the wall thickness of the external steel beam. The model of the reinforced truss
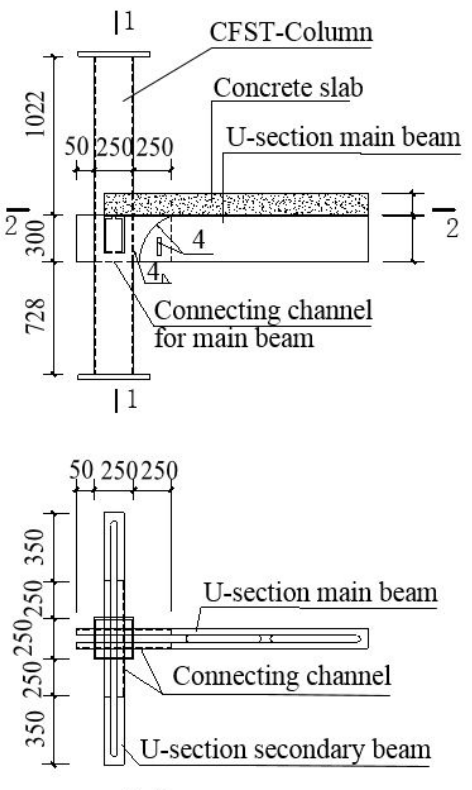

$\underline{2-2}$

Fig. 3. SJ-1 dimensional structure details

floor bearing plate is TD3-90. Detailed dimensions of SJ-1 are shown in Fig. 3.

Fig. 4 shows the processing conditions of test specimens. The steel tube column of the specimen was the finished square steel tube, and the U-shaped steel beam was processed by opening the side wall of the finished rectangular tube. The channel steel was formed using coldformed steel plates. TD3-90 standard plate was used for the bearing steel truss floor. The concretes of beam and slab were poured and tamped at one time. Layered casting method was used to increase the density of concrete in the steel tube column. Concrete at the lower part of the joint was poured before that at the upper part.
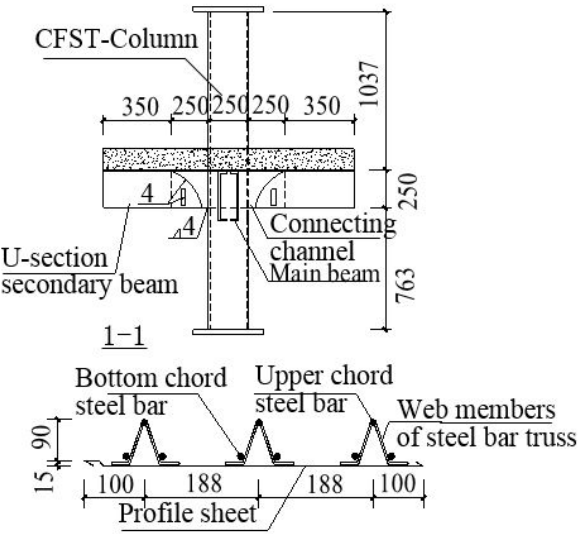

Details of steel bar truss deck

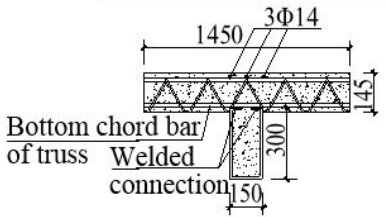

(a) Situation of channel steel through the column

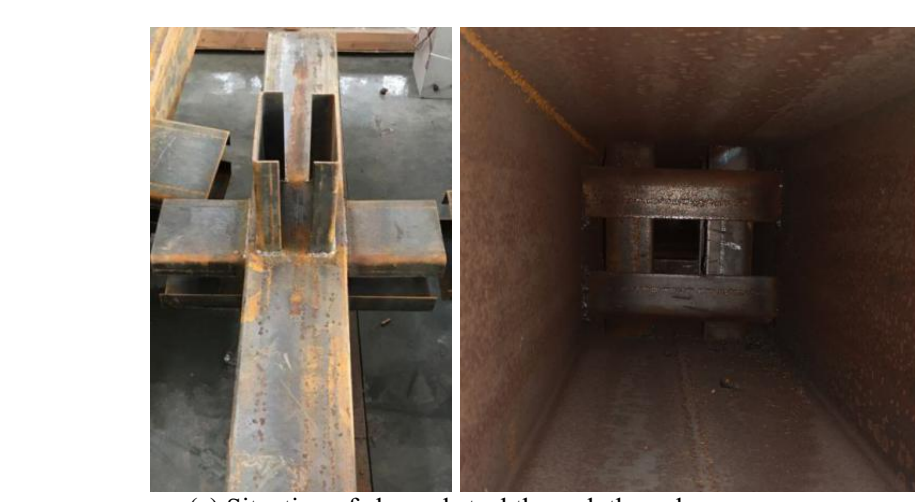

Fig. 4. Test specimen processing conditions

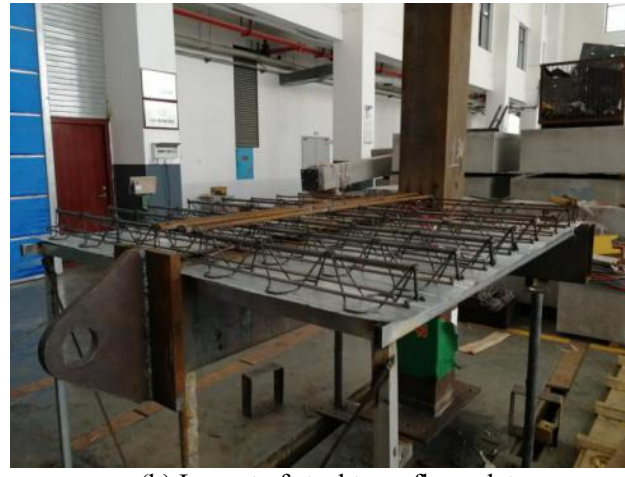

(b) Layout of steel truss floor plate 
Zaihua Zhang, Guangxiang Mao, Ran He, Alin Xiao and Zelong Liu/

Journal of Engineering Science and Technology Review 14 (4) (2021) 40 - 52

Table 1. Specimen dimensions

\begin{tabular}{|c|c|c|c|}
\hline \multicolumn{2}{|r|}{ Specimen number } & SJ-1 & $\mathrm{SJ}-2$ \\
\hline Column & $\begin{array}{c}\text { Square steel tube } \\
\left(b_{c} \times b_{c} \times t-H\right) \\
\text { Concrete }\end{array}$ & $\begin{array}{c}250 \times 250 \times 6-2050 \\
\text { C } 30\end{array}$ & $\begin{array}{c}250 \times 250 \times 6-2050 \\
\mathrm{C} 30\end{array}$ \\
\hline Main beam & $\begin{array}{l}\text { Outer U-shaped steel beam } \\
\qquad\left(h \times b \times b_{1} \times t_{1}-l\right) \\
\text { Floor width }\left(b_{f}\right) \\
\text { Floor thickness }\left(h_{c}\right) \\
\text { Negative bending moment reinforcement } \\
\text { Positive bending moment reinforcement } \\
\text { Concrete }\end{array}$ & $\begin{array}{c}300 \times 150 \times 50 \times 4-1500 \\
1450 \\
140 \\
2 \Phi 16 \\
4 \Phi 22 \\
\text { C } 30 \\
\end{array}$ & $\begin{array}{c}400 \times 150 \times 50 \times 4-1500 \\
1450 \\
140 \\
2 \Phi 16 \\
4 \Phi 16 \\
\text { C } 30\end{array}$ \\
\hline $\begin{array}{l}\text { Through-channel } \\
\text { steel }\end{array}$ & $\begin{array}{c}\text { Main beam } \\
\left(h_{s} \times b_{s} \times t_{s}-l_{s}\right) \\
\text { Secondary beam } \\
\left(h_{s} \times b_{s} \times t_{s}-l_{s}\right)\end{array}$ & $\begin{array}{l}292 \times 50 \times 6-550 \\
242 \times 50 \times 6-750\end{array}$ & $\begin{array}{l}392 \times 50 \times 6-550 \\
342 \times 50 \times 6-750\end{array}$ \\
\hline
\end{tabular}

\subsection{Material properties}

According to requirements of the tensile test method for metallic materials (GB/ T228-2010), material properties of steel samples were tested and nominal strength of all steel members was obtained. Components were obtained from square steel tube columns, U-shaped steel, channel steel, and reinforcing steel bars. Cubic compressive strength of the concrete at test dates of 28 and $94 \mathrm{~d}$ was determined according to the standard of performance test method for ordinary concrete mixture (GB/T50081-2016). Material properties are listed in Tables 2 and 3.

Table 2. Material properties for steel

\begin{tabular}{c|c|c|c|c}
\hline Steel sample & Size $(\mathbf{m m})$ & $f_{\mathrm{y}}(\mathrm{Mpa})$ & $f_{\mathrm{u}}(\mathrm{Mpa})$ & $\Delta \mathbf{( \% )}$ \\
\hline Steel tube & $\delta 6$ & 296 & 385 & 29 \\
U-section steel & $\delta 4$ & 270 & 351 & 33 \\
Channel steel & $\delta 6$ & 305 & 409 & 27 \\
Steel bar & $\phi 14$ & 455 & 585 & 32 \\
Profiled sheet & $\delta 1.0$ & 255 & 412 & 25 \\
\hline
\end{tabular}

Table. 3. Material properties for concrete

\begin{tabular}{c|c|c|c}
\hline \multirow{2}{*}{$\begin{array}{c}\text { Concrete } \\
\text { sample }\end{array}$} & \multirow{2}{*}{ Ec (GPa) } & \multicolumn{2}{|c}{$f_{c}(\mathrm{Mpa})$} \\
\cline { 3 - 4 } & & $\begin{array}{c}\text { Age } \\
\text { t=28 days }\end{array}$ & $\begin{array}{c}\text { Age (at testing) } \\
\text { t=94 days }\end{array}$ \\
\hline Concrete cube & 28.3 & 25.9 & 29.1 \\
\hline
\end{tabular}

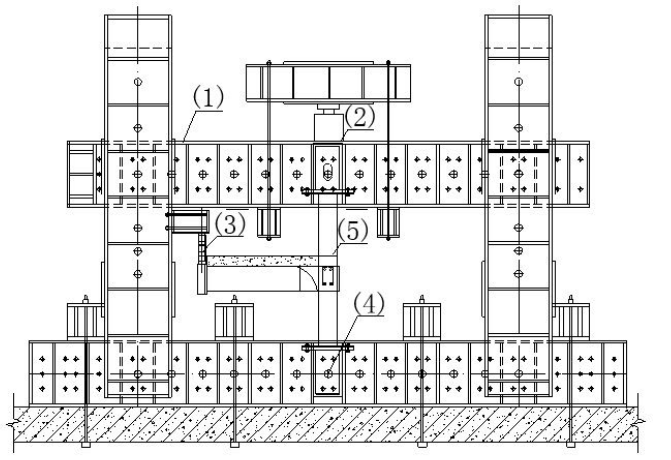

(1) Self-balancing counterforce frame, (2) Hydraulic jack at the column top, (3) Hydraulic jack at the beam end, (4) Hinged support, and (5) Test specimen.

Fig. 5. Test device

\subsection{Test Device and Loading Scheme}

A self-balancing counterforce frame was used as the test counterforce device, as shown in Fig. 5. Axial force of the concrete-filled steel tubular column was first loaded vertically using a jack and then transmitted to the selfbalancing steel frame through the distribution beam. A hydraulic jack was used to load the vertical force at the beam end. Test strain data were collected using a DH3816 resistance strain box.

The beam end loading method was used and the column bottom was set as the fixed hinge bearing without considering the effect in this test. The calculation diagram is presented in Fig. 6. The loading process is divided into two steps, namely, preloading and formal loading. Preloading was first carried out in two stages, with $10 \mathrm{kN}$ for each stage, and then unloaded in two stages. Every stage of loading (unloading) must stop for $10 \mathrm{~min}$. Fixed axial pressure was applied to the column top according to the designed axial compression ratio ( $n=0.15$ ) during formal loading. Joints were controlled via load before yielding, with $10 \mathrm{kN}$ at the loading stage, for monotonic static load tests of SJ-1 and SJ2 during the loading process. Joints were controlled using displacement after yielding. The step of loading displacement for loading was set to $+2 \mathrm{~mm}$. The failure of joints was assessed according to a load of less than $85 \%$ of the ultimate bearing capacity.

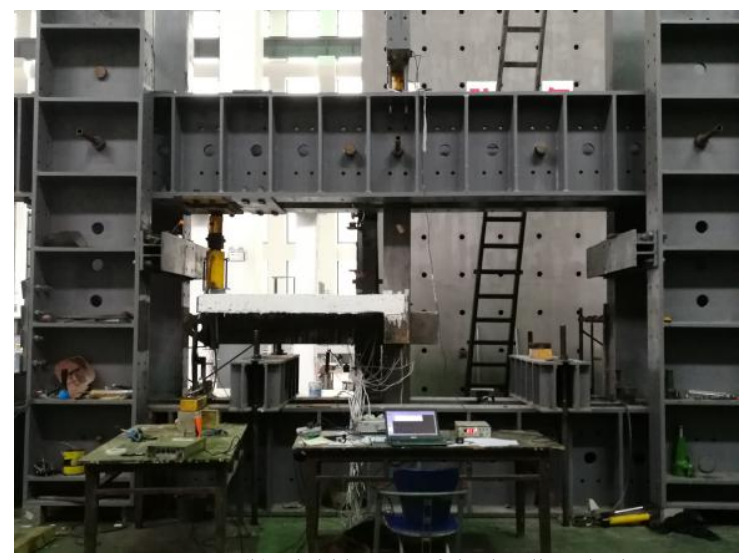

(b) Field image of the loading device 
Zaihua Zhang, Guangxiang Mao, Ran He, Alin Xiao and Zelong Liu/

Journal of Engineering Science and Technology Review 14 (4) (2021) 40 - 52

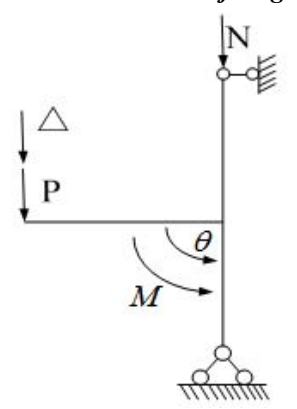

Fig. 6. Test calculation sketch

\subsection{Measurement schem}

Test contents include vertical and horizontal forces, displacement of beams and columns, and strain of key parts. Fig. 7 illustrates the layout of displacement measuring points of the specimen. Measurement contents include horizontal lateral displacement of column top and bottom, horizontal and vertical displacement of beam end, beam-column

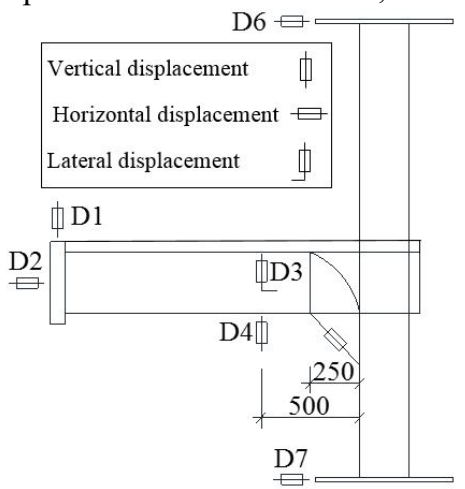

Fig. 7. Displacement measuring point layout

\section{Result Analysis and Discussion}

\subsection{Test Phenomenon and Failure Characteristics}

Bending cracks (1) and (2) appear in the concrete flange plate when the load of SJ-1 is increased to $26 \mathrm{kN}$. A new bending crack (3) is formed as the load reaches $65 \mathrm{kN}$. New bending cracks (4), (5), and (6) are formed when the load is $85 \mathrm{kN}$. Crack (3) expands continuously and penetrates the entire flange plate. Bending cracks (1), (2), and (4) penetrate when the load is $114 \mathrm{kN}$. Tiny crack (7) newly forms at the edge of the square steel tube column, the flange of the square steel tube column is separated from the concrete

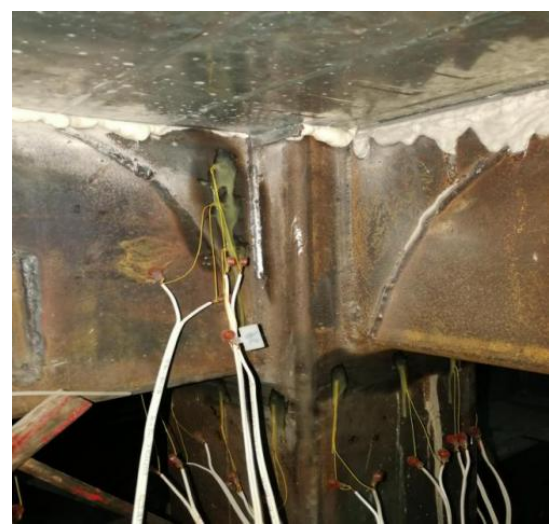

(a) Outer side of SJ-1 jointing weld

rotation angle, vertical displacement of beam end in the joint area, and lateral displacement out of plane. The test scheme of the relative rotation angle of beams and columns is shown in Fig. 8. Relative deformation of the beam-column joint area can be measured using dial indicator D5. The change of beam-column angle is measured via the numerical value of tensile change of joint area under the action of load. $\theta$ of the joint area can be calculated as follows:

$$
\theta=\arccos \left[\frac{\left(\sqrt{a^{2}+b^{2}}+\delta\right)^{2}-\left(a^{2}+b^{2}\right)}{2 a b}\right]-\frac{\pi}{2}
$$

where $\theta$ is the angle of the beam-column joint area and $\delta$ is the reading measured by dial indicator D5.

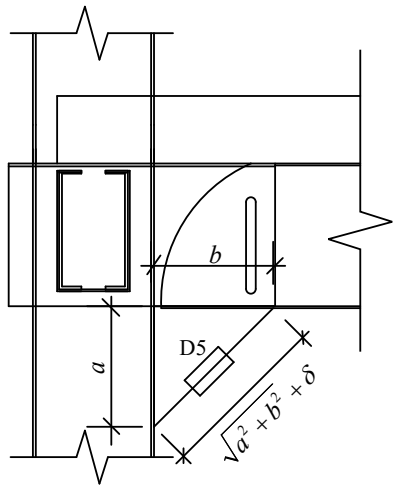

Fig. 8. Diagram of the beam-column relative angle measurement

flange plate, and longitudinal crack (8) forms around each bending crack of the flange plate at a load of $174 \mathrm{kN}$. Connecting welds of the through-channel steel, wrapped Ushaped steel beam, and steel tube column are intact (Figs. 9a and $9 \mathrm{~b}$ ); bending crack (3) on the floor surface expands to the crack with the maximum width; and flange concrete slabs on both sides of the square steel tube column are broken under an ultimate load of $198 \mathrm{kN}$. The final crack distribution is presented in Figs. 9c and 9d. The load on the specimen gradually decreases. Finally, the concrete of the flange plate near the square steel tube column cracks in tension, leading to the failure of the specimen.

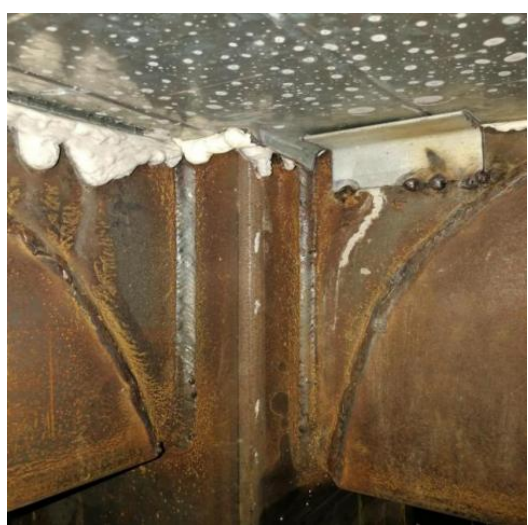

(b) Inner side of SJ-1 jointing weld 
Zaihua Zhang, Guangxiang Mao, Ran He, Alin Xiao and Zelong Liu/

Journal of Engineering Science and Technology Review 14 (4) (2021) 40 - 52

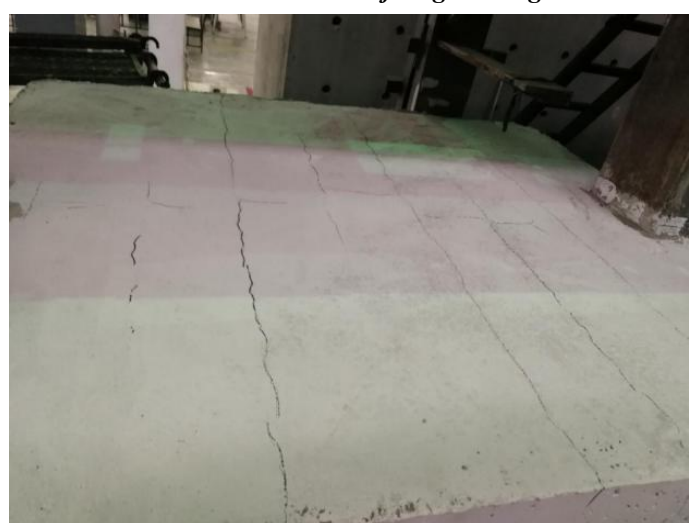

(c) SJ-1 crack picture

Fig. 9. Test result of SJ-1

The first bending crack (1) appears in the concrete floor when SJ-2 is loaded to $23 \mathrm{kN}$. New bending cracks (2), (3), and (4) appear when loaded to 52,62 , and $82 \mathrm{kN}$, respectively. The flange of the square steel tube column separates from the concrete floor when loaded to $92 \mathrm{kN}$. Cracks (1) and (4) are arranged in full length under a load of $102 \mathrm{kN}$. Original cracks expand and new cracks are formed with the gradual increase of the load. Many cracks appear in the core area of concrete floor joints and the concrete at the

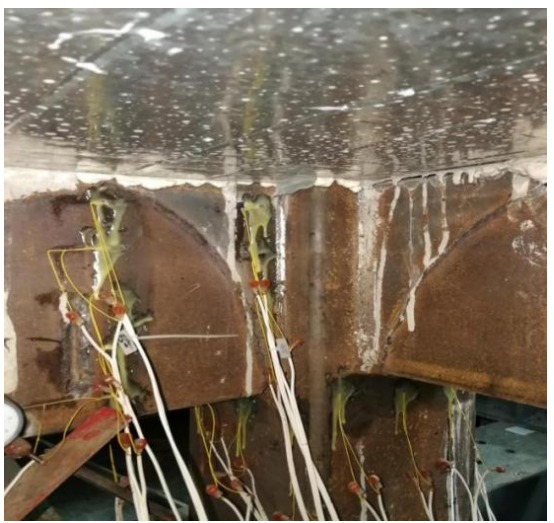

(a) Outer side of SJ-2 jointing weld

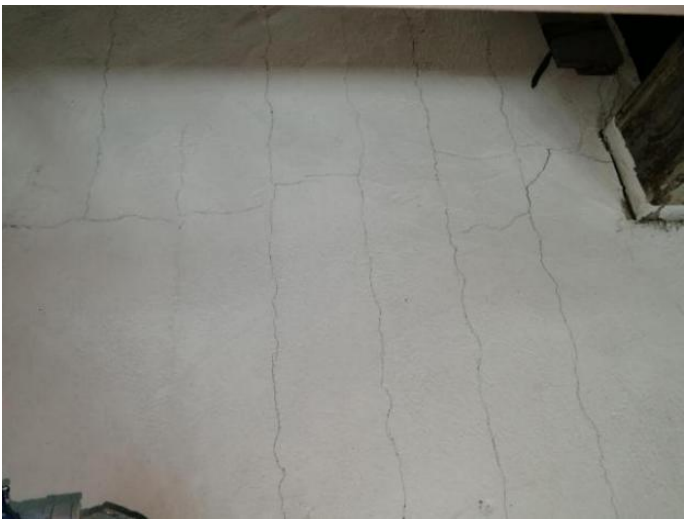

(c) SJ-2 crack picture

Fig. 10. Test result of SJ-2

\subsection{Load-displacement curve of beam end}

The load-displacement curve of each specimen is shown in Fig. 11. The vertical axis is the vertical load applied at the beam end, and the horizontal axis is the measured displacement value of the beam end. Both the displacement and the horizontal load are positive downward.

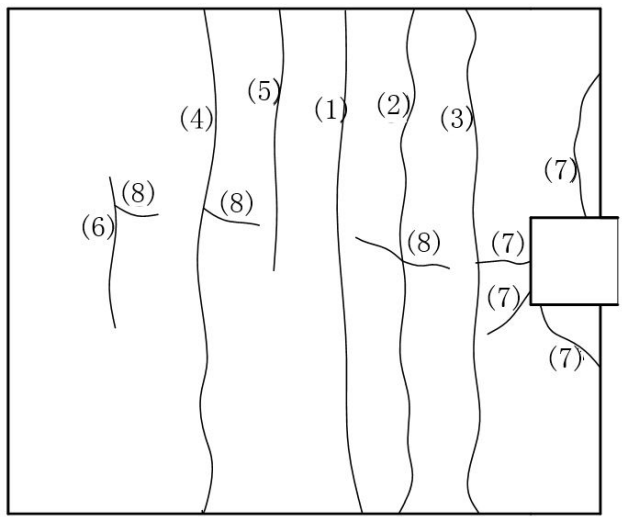

(d) Crack distribution diagram of SJ-1

edge of the column is broken when the ultimate load is 180 $\mathrm{kN}$. Meanwhile, the flange of the column is completely separated from the floor concrete and the connection weld between the lower steel beam and the column shows satisfactory condition (Figs. 10a and 10b). The final crack distribution is presented in Figs. 10c and 10d. The load then gradually decreases and the specimen is destroyed. The final failure phenomenon of the specimen is the tensile crack failure of the concrete flange plate in the joint area.

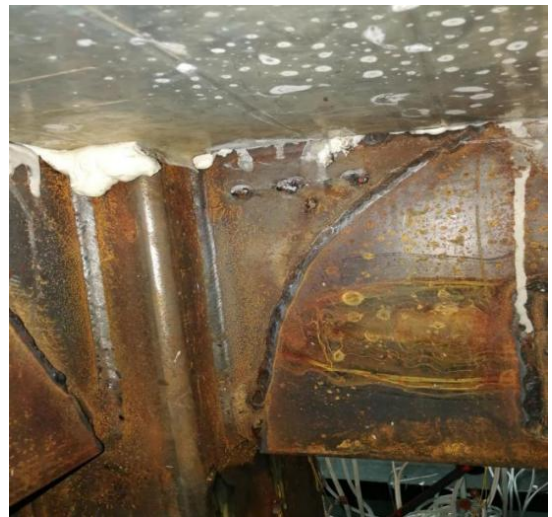

(b) Inner side of SJ-2 jointing weld

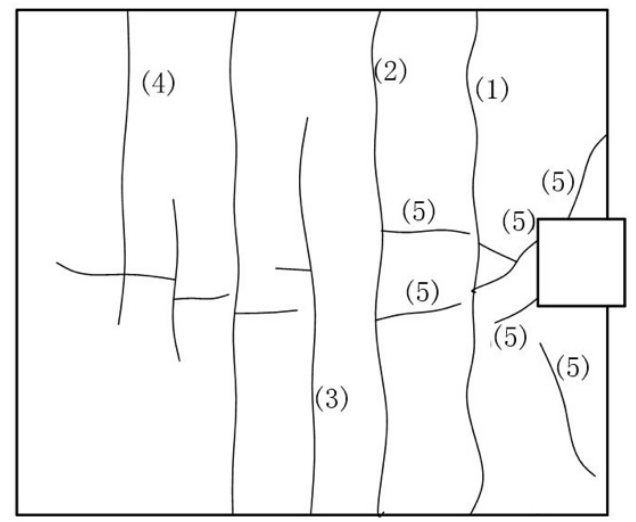

(d) Crack distribution diagram of SJ-2

The main test results of the two specimens are summarized in Table 4, where $\Delta_{c r}$ and $F_{c r}$ are the displacement and load at the beam end when the concrete flange plate cracks, respectively. $\Delta_{y}$ and $F_{y}$ are the displacement and load of the beam end when the joint yields, respectively, which can be obtained using the drawing method based on the load-displacement curve. $F_{u}$ is the ultimate bearing load of the beam end of the specimen and 
$\Delta_{u}$ is the displacement of the beam end as the beam end load decreases to $85 \%$ of the ultimate load.

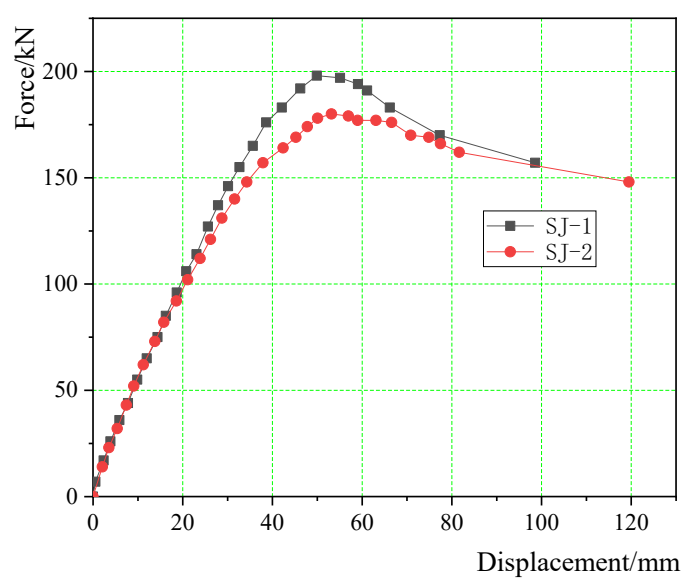

Fig. 11. Force versus displacement curves of joint

Table 4. Test results of specimens

\begin{tabular}{c|c|c|c|c|c|c|c}
\hline Number & $\begin{array}{c}\Delta_{c r} \\
\mathbf{( m m})\end{array}$ & $\begin{array}{c}F_{c r} \\
\mathbf{( k N )}\end{array}$ & $\begin{array}{c}\Delta_{y} \\
\mathbf{( m m})\end{array}$ & $\begin{array}{c}F_{y} \\
\mathbf{( k N )}\end{array}$ & $\begin{array}{c}\Delta_{u} \\
\mathbf{( m m})\end{array}$ & $\begin{array}{c}F_{u} \\
\mathbf{( m m})\end{array}$ & $\begin{array}{c}\text { Ductility } \\
\text { factor }\end{array}$ \\
\hline SJ-1 & 3.89 & 26 & 37.90 & 173 & 98.61 & 198 & 2.60 \\
SJ-2 & 3.56 & 22 & 44.21 & 167 & 119.80 & 180 & 2.71 \\
\hline
\end{tabular}

Data analysis of Fig. 11 and Table 4 showed that the loading process of two specimens includes three stages, namely, elasticity, elastoplasticity, and failure. The joint still presents relatively high bearing capacity after the ultimate tensile failure of the concrete flange plate of each specimen due to the beam end through-channel steel. The ductility of the joint at the ultimate failure is greater than 2.0, thereby indicating that the joint of the through-channel steel connection structure demonstrates improved bearing capacity and ductility.

The section of SJ-1 is smaller by $100 \mathrm{~mm}$ compared with that of SJ-2. However, the reinforcement ratio of U-shaped steel beams increases from $1.3 \%$ of SJ-2 to $3.4 \%$ of SJ-1 and the ultimate flexural capacity of SJ-1 section increases by $10 \%$ compared with that of SJ-2. Increasing the reinforcement ratio of the U-shaped steel can clearly and effectively improve the yield load and the ultimate bearing capacity of joints under negative bending moment as the ductility of the corresponding joint decreases.

\subsection{Bending moment-rotation angle curve}

Bending moment and rotation angle curves of each specimen are shown in Fig. 12. The rotation angle and the bending moment are counterclockwise positive. The rotation angle of the joint area is calculated from the reading of displacement meter no. 5 according to cosine theorem.

The bending moment-rotation angle curve demonstrated that a linear relationship exists between the bending moment and rotation angle at the beginning of load application. The rotation angle increases gradually after the plastic stage. SJ-1 and SJ-2 reach the ultimate bending moment of 297 and 270 $\mathrm{kN} \cdot \mathrm{m}$, respectively, when the rotation angle is $0.025 \mathrm{rad}$. The comparison of two specimens showed that their initial rotation stiffness is basically the same and bending momentrotation angle curves generally coincide in the elastic stage. Increasing the reinforcement ratio of U-shaped beams minimally influences the elastic stage of joints, but the bending moment of joints improves in the plastic stage.

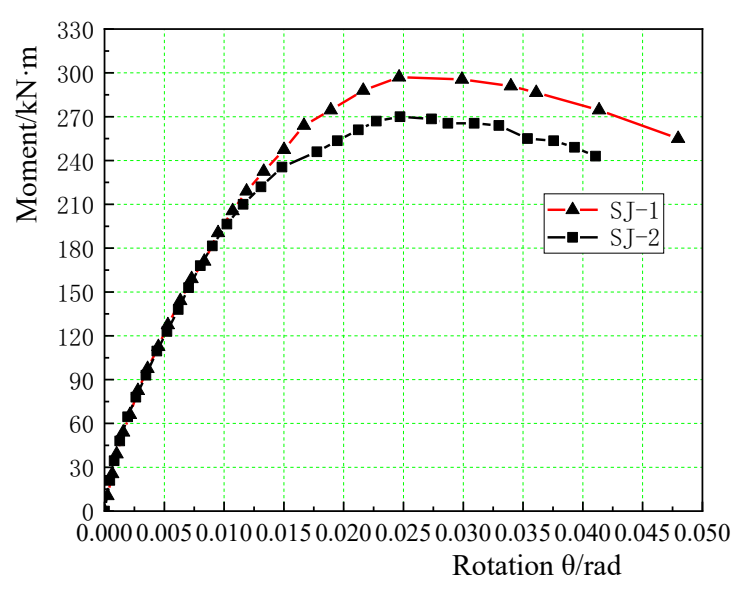

Fig. 12. Moment versus rotation curves of joint

\subsection{Finite Element Simulation of Performance of Joints}

\subsubsection{Modeling}

Finite element software ABAQUS was used to simulate and analyze joints as well as investigate the performance of novel through-channel steel beam-column joints further. Notably, model members ignore effects of geometric initial defects and residual stress.

(1) Element type and grid division

The concrete in concrete-filled square steel tubular columns and U-shaped steel composite beams was simulated using the eight-node six-cube linear solid element (C3D8R). A four-node reduced integral general shell element (S4R) was selected to simulate the square steel pipe, wrapped Ushaped beam, and through-channel steel. Steel bars in composite beams wrapped with U-shaped concrete were simulated using 3D two-node truss element (T3D2). The grid was divided using local encryption of joint area to improve the calculation accuracy. The model grid division is shown in Fig. 13.

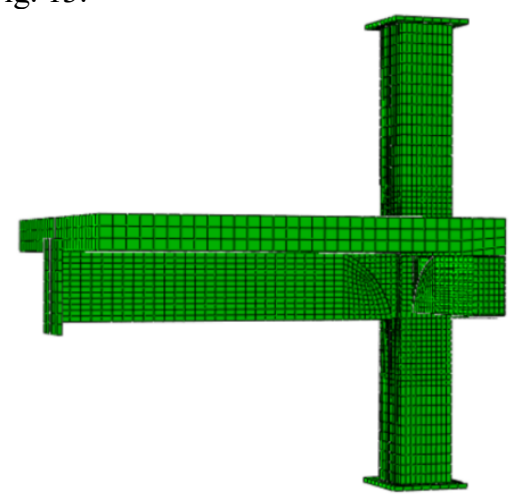

Fig. 13. ABAQUS model grid element

(2) Constitutive model of materials

ABAQUS provides a damage plastic model of concrete, and the stress-strain relationship between tension and compression is determined according to Code for Design of Concrete Structures (GB50010-2010). The stress-strain curve of steel adopts a simplified threefold line model without considering the degradation strength of steel, as shown in Fig. 14b. The Poisson ratio is 0.3 . 
Zaihua Zhang, Guangxiang Mao, Ran He, Alin Xiao and Zelong Liu/

Journal of Engineering Science and Technology Review 14 (4) (2021) 40 - 52

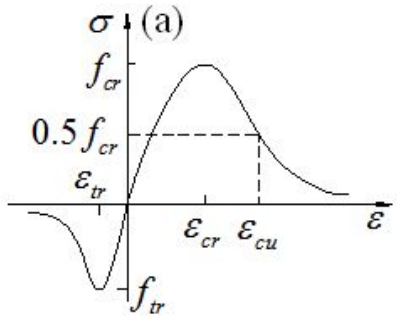

(a) Constitutive model of concrete

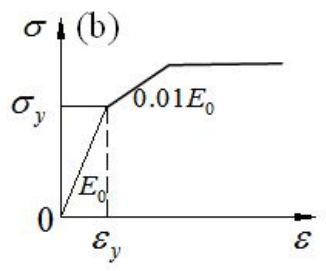

(b) Constitutive model of column reinforcement

Fig. 14. Material constitutive model

(3) Model contact setting

Separation after contact was allowed for the contact between the concrete in the square steel tube column and the steel tube wall as well as the hard contact between the Ushaped beam and the concrete in the beam in the normal direction. Penalty contact was used in the tangential direction, and relative slip was allowed. The friction coefficient was 0.3 . Merge command was applied to merge the through-channel steel and steel tube column wall. The welding of U-shaped girder and channel steel was realized using binding command. Similarly, the concrete slab and the upper flange of the U-shaped main beam were also restrained using the binding command. Embedded region command was used to embed the concrete for the reinforcement in the concrete floor.

(4) Boundary conditions and load application

Boundary conditions of the model were set according to the above test-loading diagram. Column top, column bottom, and beam end were coupled to the surface of the rigid base plate through reference points, and boundary conditions can be applied to reference points, as shown in Fig. 15. Translation constraints in $\mathrm{X}$ and $\mathrm{Y}$ directions $(\mathrm{Ux}=\mathrm{Uy}=\mathrm{URy}=\mathrm{URz}=0)$ were applied to reference points at the column top, and the axial pressure was applied by adding concentrated force to reference points. Translation constraints in $\mathrm{X}, \mathrm{Y}$, and $\mathrm{Z}$ directions were applied to the reference point at the column foot to simulate the articulation $(\mathrm{Ux}=\mathrm{Uy}=\mathrm{Uz}=\mathrm{URy}=\mathrm{URz}=0)$. External load was

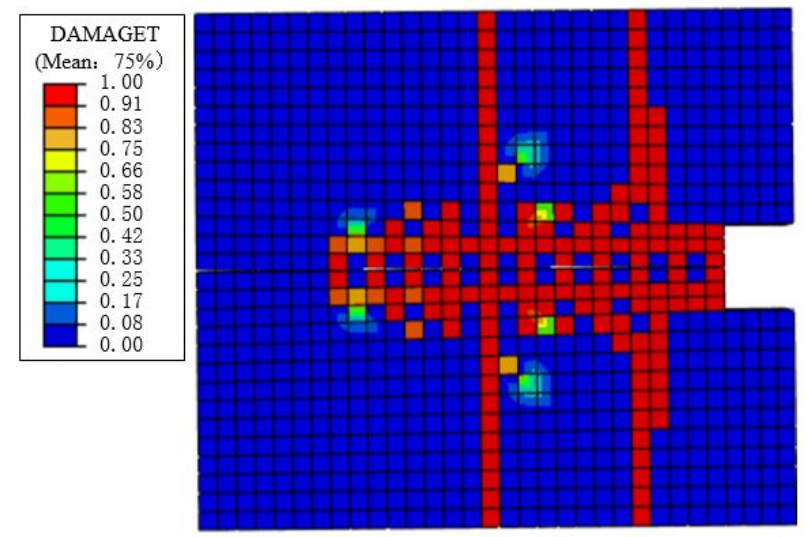

(a) SJ-1

Fig. 16. Tensile plastic damage of concrete floor

Fig. 16 compares the load-displacement curves of two specimens with those obtained via finite element method. The finite element calculation results are consistent with the experimental results. The slope of finite element curve slightly increases in the elastic stage because the finite applied to the reference point at the beam end in the form of displacement.

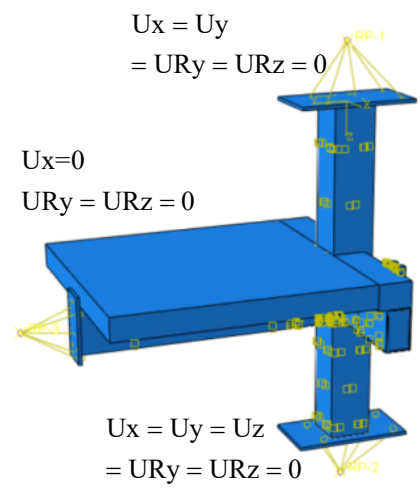

Fig. 15. Boundary conditions of the specimen model

\subsubsection{Modeling}

Fig. 16 presents the distribution diagram of tensile plastic damage of concrete floors of SJ-1 and SJ-2 under negative bending moment. The concrete can be considered broken when the tensile plastic damage value is close to 1.0. According to the crack diagram of the test site, many transverse cracks exist in the concrete floor and the concrete floor near the steel tube column is partially broken. This finding is consistent with the phenomenon observed via finite element analysis.

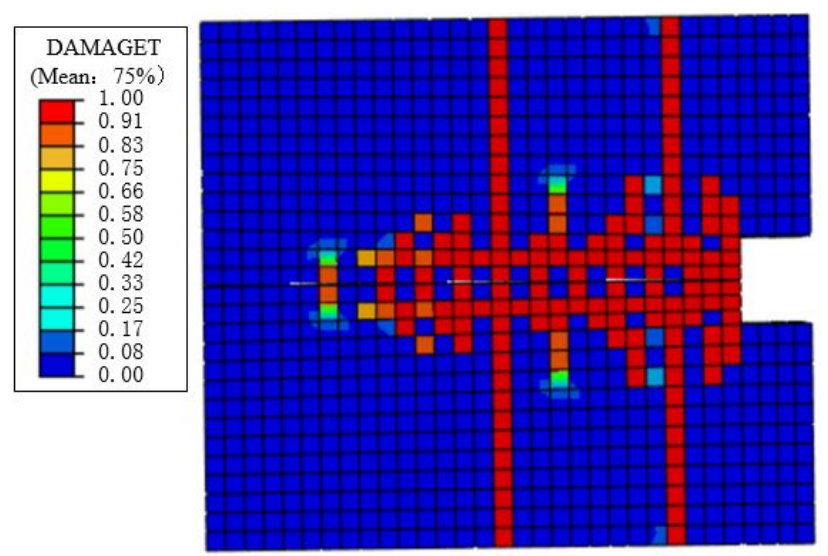

(b) SJ-2

element model ignores the influence of initial defects, such as residual stress, weld, and compactness of joint core concrete. The ultimate load is basically the same. SJ-1 is approximately $3.5 \%, \mathrm{SJ}-2$ is around $7.5 \%$, and the error is within an acceptable range. The finite element modeling method used in this study is clearly accurate and reliable. 


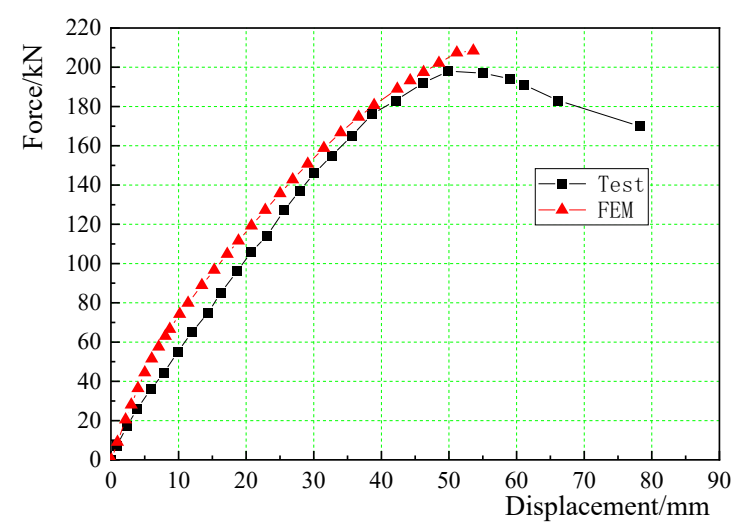

(a) $\mathrm{SJ}-1$

Fig. 17. Comparison of force-displacement curves

\subsubsection{Parameter analysis}

On the basis of the corresponding model of test specimens, the height of beam section, wall thickness of steel tube column, and axial compression ratio of concrete-filled steel tube column of composite joints were adjusted. The influence of different parameters on the joint performance under the action of positive and negative bending moment of the beam was analyzed.

(1) Height of U-shaped steel main girder

The section height of the U-shaped steel main girder is set to $250,300,350$, and $400 \mathrm{~mm}$ while other parameters of the composite joint remain unchanged to obtain the loaddisplacement curve of the beam end and the variation trend

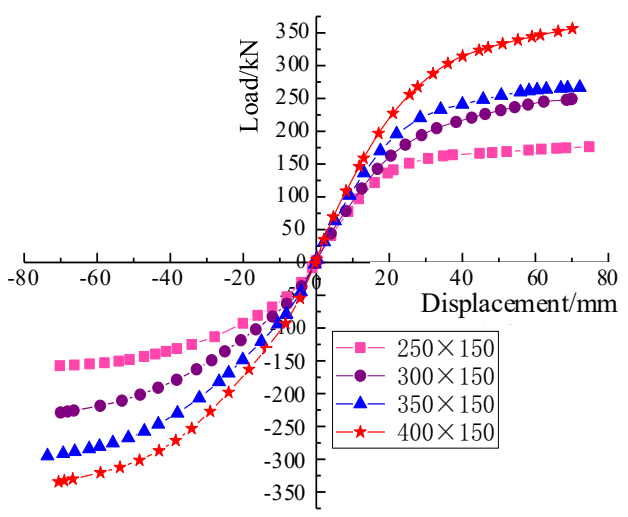

(a) Influence of height of main beam on load displacement curve of beam end

Fig. 18. Analysis results of changing the height of U-shaped steel beam

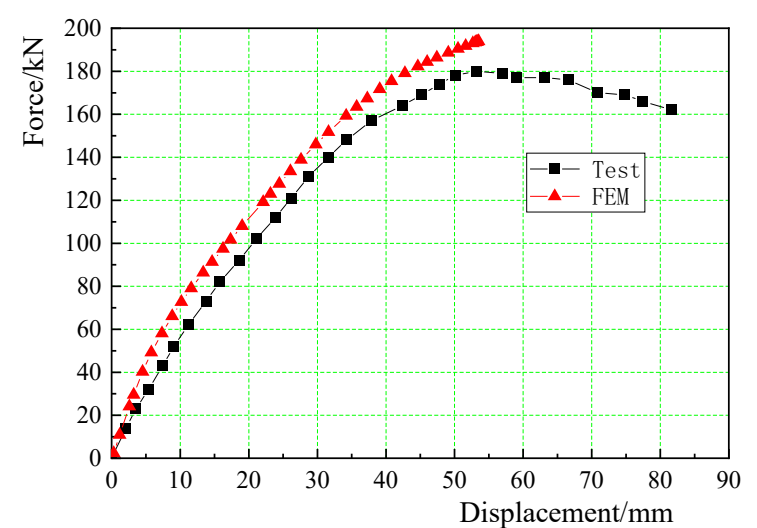

(b) SJ-2

of ultimate bearing capacity (Fig. 18). From the analysis results, it can be concluded that: (1) With the increase of the height of the main girder, the stiffness of the joint increases slowly and the ductility decreases; (2) Increasing the height of the U-shaped beams can significantly improve the flexural capacity of the joints, and the ultimate bearing capacity increases linearly with the increase of the beam height. As shown in Table 5, the ultimate bearing capacity of the joint increases by $3.0 \%$ for every $1 \%$ increase in the steel consumption of the joint compared with the model with a height of $250 \mathrm{~mm}$. Increasing the bearing capacity of the joint by increasing the beam height is economical in engineering design.

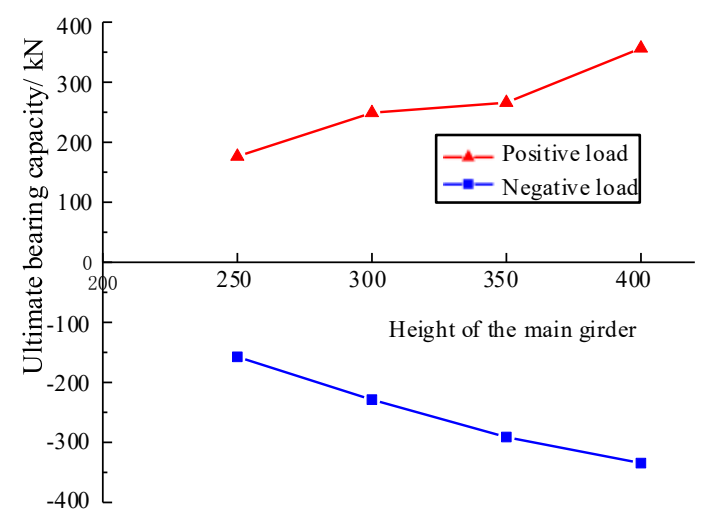

(b) Influence of height of main beam on ultimate bearing capacity

Table 5. Influence of U-shaped beam height on ultimate bearing capacity of joints

\begin{tabular}{|c|c|c|c|c|}
\hline $\begin{array}{c}\text { Height of U-shaped beam } \\
(\mathrm{mm})\end{array}$ & 250 & 300 & 350 & 400 \\
\hline $\begin{array}{l}\text { Ultimate bearing capacity of joints } \\
(\mathrm{kN})\end{array}$ & 176.4 & 249.1 & 266 & 356.5 \\
\hline $\begin{array}{c}\text { Increase of ultimate bearing capacity } \\
(\%)\end{array}$ & - & 41.2 & 50.79 & 102.1 \\
\hline$\frac{\text { Increase of ultimate bearing capacity }}{\text { Increase ofsteel consumption }}$ & - & 3.0 & 1.9 & 2.5 \\
\hline Increase of steel consumption (\%) & - & 13.6 & 27.2 & 40.8 \\
\hline
\end{tabular}

(2) Width-thickness ratio of column

Based on SJ-1, the wall thickness of the concrete-filled square steel tube column is adjusted to $6,8,10$, and $12 \mathrm{~mm}$ for comparative analysis. The analysis results are shown in Fig. 19. Increasing the column wall thickness exerts little effect on the ultimate bearing capacity of joints because the failure of each model is the failure of the beam end. The flange of the beam end yields first and then the ultimate bearing capacity is reached during the loading process. The entire joint specimen follows the basic rule of "strong column and weak beam." The improvement of the ultimate 
Zaihua Zhang, Guangxiang Mao, Ran He, Alin Xiao and Zelong Liu/

Journal of Engineering Science and Technology Review 14 (4) (2021) 40 - 52

bearing capacity of edge joints is slight when the wall thickness of the steel tube column is increased.

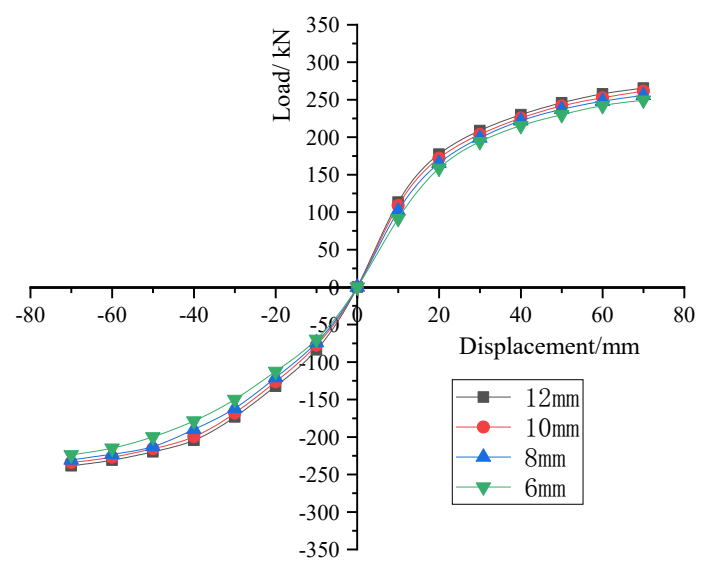

(a) Influence of width-thickness ratio of column on loaddisplacement curve of beam end

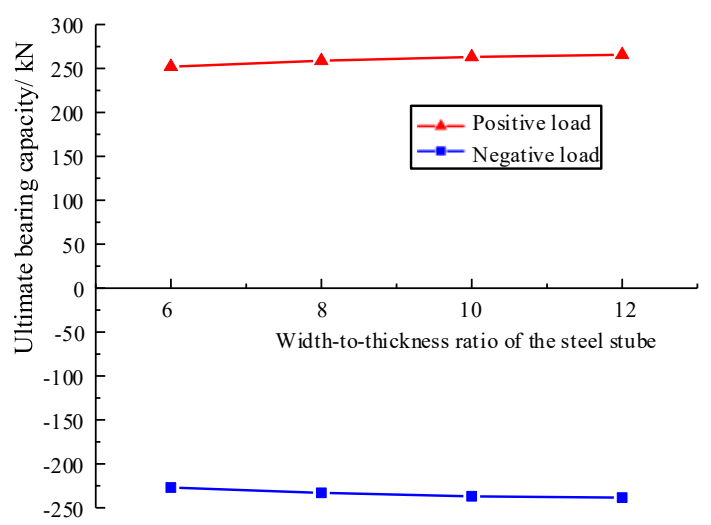

(b) Influence of width-thickness ratio of column on bearing capacity

Fig. 19. Effect of width-to-thickness ratio of column

(3) Axial compression ratio

Based on SJ-1 section parameters, the axial force of concrete-filled steel tubular columns is analyzed and is calculated according to Technical Code for Concrete-filled Steel Tubular Structures (GB50936-2014), and the bearing capacity of joints is investigated at axial compression ratios of $0.0,0.2,0.4$, and 0.6 . The analysis results are shown in Fig. 20.

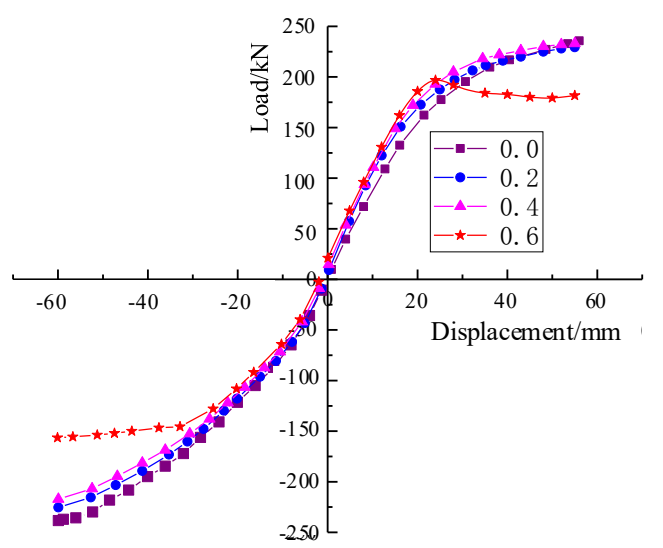

(a) Influence of axial compression ratio on load-displacement curve of beam end

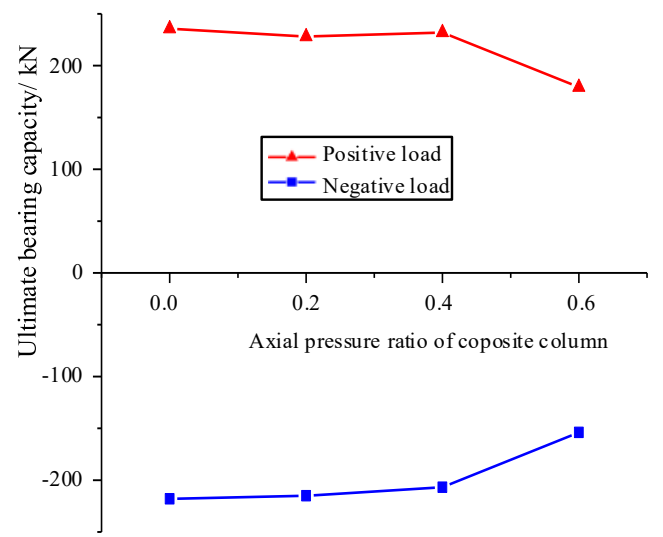

(b) Influence of axial compression ratio on bearing capacity of joints

Fig. 20. Effect of axial load ratio of column

The analysis results in Fig. 20 demonstrated that loaddisplacement curves basically coincide in the entire stage when the axial compression ratio changes between 0.0 and 0.4 . The ultimate bearing capacity of joints reduces in varying degrees when the axial compression ratio reaches 0.6. Steel tube columns undergo compression and bending failure and the change of failure mode leads to the rapid reduction of the bearing capacity of joints under large axial compression ratios. The change of axial compression ratio can significantly influence the bearing capacity of joints. The bearing capacity will reduce sharply when the axial compression ratio is greater than 0.6. If the axial compression ratio is less than or equal to 0.6 , then the bearing capacity can basically remain unchanged. Limiting the axial compression ratio of columns is necessary to use the composite frame structure in residential buildings and ensure the improved bearing capacity of joints.

\section{Conclusions}

A composite joint based on channel steel through connection structure was proposed and an experimental investigation on the monotonic bearing capacity of the joint under negative bending moment was carried out to meet structural requirements of the beam-column connection of composite frame of small-section concrete-filled steel tubular columnU-shaped steel composite beam in residential buildings. Meanwhile, the influence of beam section height, widththickness ratio of steel tubular column section, and axial compression ratio of column on the bearing capacity of the joint was discussed on the basis of the parameter analysis of the ABAQUS finite element model. The following conclusions can be drawn:

(1) On the basis of beam-column joints of the channel steel through the connection structure, the composite frame of concrete-filled steel tubular columns and U-shaped steel composite beams effectively realizes the continuous penetration of frame beams in the beam-column joint domain. It is a new type of composite joint structure with high bearing capacity and reliable force transmission suitable for small-section concrete-filled steel tubular columns and steel-concrete composite beams in residential buildings.

(2) The failure mode of the new composite joint of concrete-filled steel tubular column-U-shaped steel composite beam is mainly tensile failure of the concrete flange plate in the core area of the joint under the action of 
negative bending moment. The connection between the Ushaped steel beam at the lower part of the core area of the joint and the square column is intact and the ductility coefficient of the joint is greater than 2.0, thereby indicating satisfactory bearing capacity and ductility performance.

(3) Increasing the reinforcement ratio of the U-shaped steel can effectively improve the yield load and ultimate bearing capacity of joints while reducing the ductility of corresponding joints under the action of negative bending moment.

(4) The height of the U-shaped composite beam significantly influences the bearing capacity of joints, and the bearing capacity increases linearly with the increase of the beam height. The width-thickness ratio of steel tube columns exerts minimal influence on the bearing capacity of joints when it meets requirements of "strong columns and weak beams." Increasing the thickness of the column wall fails to enhance the bending capacity of joints effectively. The change of axial compression ratio can significantly influence the bearing capacity of joints. The failure mode of joints is the main compression bending failure and the bending bearing capacity decreases sharply when the axial compression ratio is greater than 0.6. However, the bearing capacity is only slightly affected by the axial compression ratio when the axial compression ratio is less than or equal to 0.6 .
On basis of the experimental investigation and finite element analysis, reliability of the structural mode of channel steel through joints of USCB-to-CFSTBC composite frame was proven. The simple structure accords with the design concept of hidden beams and columns in residential buildings. Prefabrication of through-channel steel and steel tube column in the factory enhances the convenience of the connection structure to field construction and its applicability to practical residential structural engineering. The test results can provide a reference for the wide application of the new composite joint. Positive moment bearing and seismic performance of the joint can be explored further in a follow-up investigation and the seismic design method of the joint can be developed on the basis of inductive analysis given that only negative moment monotonic loading is considered in the test of this study.

\section{Acknowledgements}

This work was supported by the Hunan Natural Science Foundation (2018JJ2020 and 2020JJ5018) and the Scientific Research Project of Education Department of Hunan Province (19A095, 19B099, and 18C0837)

This is an Open Access article distributed under the terms of the Creative Commons Attribution License.

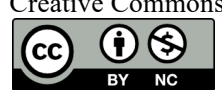

\section{References}

1. Sun, Y. K., Liu, Q. X., Liu W., "Research progress and key issues analysis on U-shape steel encased composite beams". Building Structure, 48(S1), 2018, pp.470-476,(in Chinese).

2. Zhou, X. J., Lin, Y., "Theoretical research and design application of composite U-shaped steel concrete beams". Beijing: Science Press, China, 2016, pp.10-20,(in Chinese).

3. Zhang, T., "Load bearing behavior and test research of simply supported U-section steel-encased concrete composite beams". Master thesis of Shandong Jianzhu University, China, 2021, pp.15 , (in Chinese).

4. Nie, J. G., Wang, J. J., Gou, S. G., et al., "Technological development and engineering applications of novel steel-concrete composite structures". Frontiers of Structural and Civil Engineering 13(1), 2019, pp.1-14.

5. Zhong S. T., "The advantages of concrete filled steel tube columns applied in residence buildings". Steel Structure, 17(58), 2002, pp.16-19.

6. Liu Y., Guo, L. H., Zhang, S. M., "Cyclic loading tests of composite joints between concrete-filled square steel tubular column and composite beam with U-shaped steel girder". Journal of Building Structures, 39(6), 2018,pp.131-140,(in Chinese).

7. Lin, Y., Zhou, X. J., Han, X. Y., et al., "Study on seismic behavior of concrete-filled square steel tubular column to steel-encased concrete composite beam joint with through diaphragm". Journal of Civil Engineering, 47(S2), 2014, pp.8-13,(in Chinese).

8. Lin, Y., Zhou, X. J., "Experimental study on the seismic behavior of the joint of concrete-filled square steel tubular column to to steelencased concrete composite beam". Progress in Building Steel Structure, 20(1), 2018, pp. 82-89,(in Chinese).

9. Zhou, X. J., Wang, X. Y., Zhang, Y. Z., "The analysis of the antiseismic capacity of joints in composite frame of concrete encased by U-shaped steel plate". Journal of Civil Engineering, 43(S1), 2010, pp.163-168,(in Chinese).

10. Ding, X. B., Yang, F., "Experimental investigation and finite element analysis of concrete-filled square steel tubular column to cold bending U-shaped steel beam joint". Industrial Construction, 49(3), 2019, pp.153-189,(in Chinese).

11. Oehlers D J, Wright H D, Burnet M J. "Flexural strength of profiled beams". Journal of Structural Engineering, 120(2), 1994, pp.378393.
12. Hossain, K. M. A., "Experimental \& theoretical behavior of thin walled composite filled beams". Electronic Journal of Structural Engineering, 3(3), 2003, pp.117-139.

13. Kim S M, Kim K S. "A Study on the strength evaluation for T-type composite beam". Journal of Korean Society of Steel Construction, 15(4), 2003, pp.467-474.

14. Kim S S, Kim S M, Kim S B, et al. "An experimental study on the behavior of the t-type steel composite beam". Journal of Korean Society of Steel Construction, 16(2), 2004, pp.225-233.

15. Kim S. B., Lee C. N., and Kim S.S., "Experimental study on the flexural performance of bottle neck TSC beam". Journal of the Architectural Institute of Korea Structure \& Construction, 22(1), 2006, pp.11-17.

16. Kim J H, Lim J J, Lee S H, et al. "Design method of thin steel-plate composite (TSC) beam based on Eurocode". Steel Construction, 13, 2019, pp.15-26.

17. Zhou, X.H., Zhao Y.,Liu J. P., et al. "Bending experiment on a novel configuration of cold-formed U-shaped steel-concrete composite beams". Engineering Structures, 180, 2019, pp.124-133.

18. Liu J. P., Zhao Y, Chen Y F, et al. "Flexural behavior of rebar truss stiffened cold-formed U-shaped steel-concrete composite beams". Journal of Constructional Steel Research, 150, 2018, pp.175-185.

19. Zhao Y, Zhou X. H., Yang Y. L., et al., "Negative bending behavior of novel U-shaped steel and concrete composite beams". Engineering Structures, 237, 2021:112217.

20. Zhao Y, Zhou X. H., Yang Y. L., et al., "Stiffness and cracking behavior of new U-shaped steel and concrete composite beam under negative bending". Journal of Structural Engineering, 146(5), 2020: 04020046.

21. Zhao Y, Zhou X. H., Yang Y. L., et al., "Shear behavior of a novel cold-formed U-shaped steel and concrete composite beam". Engineering Structures, 200, 2019: 109745.

22. Turetta, M., "Development of an innovative U-shaped steel-concrete composite beam solution: experimental and numerical studies on the mechanical behaviour". Doctoral Dissertation of Université de Lorraine, Université du Luxembourg, 2019, pp.48-58.

23. Turetta, M., Odenbreit, C., Khelil, A., et al., "Investigation on the flexural behavior of an innovative U-shaped steel-concrete composite beam". Steel and Composite Structures, 34(3), 2020, pp.441-452. 
Zaihua Zhang, Guangxiang Mao, Ran He, Alin Xiao and Zelong Liu/

Journal of Engineering Science and Technology Review 14 (4) (2021) 40 - 52

24. Lee M H, Oh M H, Kim Y H, et al., "Experimental Study on the Shear Capacity of Slim AU Composite Beam". Journal of the Korean Association for Spatial Structures, 17(3), 2017, pp.99-105.

25. Kim D B, Lee M H, Lee Y S, et al., "The Flexible Capacity Evaluation about Composite-stage of Semi Slim AU Composite Beam for Saving Story Height". Journal of Korean Society for Advanced Composite Structures, 9(1), 2018, pp.17-25.

26. Liu Y, Guo L. H., Qu B., et al., "Experimental investigation on the flexural behavior of steel-concrete composite beams with U-shaped steel girders and angle connectors". Engineering Structures, 131, 2017, pp.492-502.

27. Guo, L. H., Yong L., Bing, Q., "Fully composite beams with Ushaped steel girders: Full-scale tests, computer simulations, and simplified analysis models". Engineering Structures, 177, 2018, pp.724-738.

28. Liu Y, Guo L. h., Qu B. "Shear Transfer Capacity of Angle Connectors in U-Shaped Composite Girder: Experimental and Numerical Study”. Journal of Structural Engineering, 147(5),2021: 04021046.

29. Keo P, Lepourry C, Somja H, et al. "Behavior of a new shear connector for U-shaped steel-concrete hybrid beams". Journal of Constructional Steel Research, 145, 2018, pp.153-166.

30. Park H G, Hwang H J, Lee C H, et al. "Cyclic loading test for concrete-filled U-shaped steel beam-RC column connections", Engineering structures, 36, 2012, pp.325-336.

31. Hwang $\mathrm{H} \mathrm{J}$, Park $\mathrm{H}$ G, Lee $\mathrm{C} \mathrm{H}$, et al. "Seismic resistance of concrete-filled U-shaped steel beam-to-RC column connections". Journal of Korean Society of Steel Construction, 23(1), 2011, pp.83-97.

32. Lee $\mathrm{C} \mathrm{H}$, Park H G, Park $\mathrm{CH}$, et al. "Cyclic seismic testing of composite concrete-filled U-shaped steel beam to H-shaped column connections". Journal of Structural Engineering, 139(3), 2013, pp.360-378.
33. Park C H, Lee $\mathrm{C} \mathrm{H}$, Park H G, et al. "Cyclic Seismic Testing of Cruciform Concrete-Filled U-Shape Steel Beam-to-H Column Composite Connections". Journal of Korean Society of Steel Construction, 23(4), 2011, pp.503-514.

34. Park H G, Lee $\mathrm{C} \mathrm{H}$, Park $\mathrm{C} \mathrm{H}$, et al. "Cyclic seismic testing of concrete-filled U-shaped steel beam-to-steel column connections". Journal of Korean Society of Steel Construction, 23(3), 2011, p.337-347.

35. Hwang H J, Eom T S, Park H G, et al., "Cyclic Loading Test for TSC Beam- PSRC Column Connections". Journal of Korean Society of Steel Construction, 25(6), 2013, pp.601-612.

36. Hwang H J, Eom T S, Park H G, et al., "Cyclic loading test for beam-column connections of concrete-filled U-shaped steel beams and concrete-encased steel angle columns". Journal of Structural Engineering, 141(11), 2015: 04015020.

37. Kim S. B., Ham J. T., Lee C. N., et al., "Study on the Structural Behavior of TSC Beam- to- SRC Column Connection". Journal of the Architectural Institute of Korea Structure \& Construction, 22(6), 2006, pp.55-62.

38. Lu, M., "Nonlinear finite element analysis on mechanical properties of the joints of steel-encased concrete composite beam to concretefilled steel tube column". Master thesis of Jiangsu University, China, 2010, pp.1-8, (in Chinese).

39. $\mathrm{Wu} \mathrm{Z} \mathrm{H,} \mathrm{"Study} \mathrm{on} \mathrm{shear} \mathrm{behavior} \mathrm{of} \mathrm{new} \mathrm{type} \mathrm{joint} \mathrm{between}$ concrete-filled square steel tubular column and outer U-shaped steel concrete composite beams". Master thesis of Shandong Jianzhu University, China, 2017, pp.3-8, (in Chinese).

40. Lepourry C, Heng P, Somja H, et al., "Experimental and numerical investigation on the behaviour of the joint between a U-Shaped concrete-steel beam and a concrete filled steel square column".In: 2019 Fib Symposium of Concrete Innovations in Materials, Design and Structures, Krakow, Poland: Springer, 2019: 02269008.

41. Heng P, Lepourry C, Somja H, et al. "Behaviour of a joint between a U-shaped steel-concrete beam and a concrete-filled steel tubular column". Journal of Constructional Steel Research, 175, 2020:106322. 